\title{
Food intake biomarkers for green leafy vegetables, bulb vegetables, and stem vegetables: a review
}

\author{
Elske M. Brouwer-Brolsma ${ }^{1 *+}$, Beate Brandl ${ }^{2 \dagger}$, Marion E. C. Buso ${ }^{1}$, Thomas Skurk ${ }^{2,3}$ and Claudine Manach ${ }^{4}$
}

\begin{abstract}
Background: Numerous studies acknowledged the importance of an adequate vegetable consumption for human health. However, current methods to estimate vegetable intake are often prone to measurement errors due to self-reporting and/or insufficient detail. More objective intake biomarkers for vegetables, using biological specimens, are preferred. The only concentration biomarkers currently available are blood carotenoids and vitamin C, covering total fruit and vegetable intake. Identification of biomarkers for specific vegetables is needed for a better understanding of their relative importance for human health. Within the FoodBAll Project under the Joint Programming Initiative "A Healthy Diet for a Healthy Life", an ambitious action was undertaken to identify candidate intake biomarkers for all major food groups consumed in Europe by systematically reviewing the existent literature. This study describes the review on candidate biomarkers of food intake (BFIs) for leafy, bulb, and stem vegetables, which was conducted within PubMed, Scopus and Web of Science for studies published through March 2019.

Results: In total, 65 full-text articles were assessed for eligibility for leafy vegetables, and 6 full-text articles were screened for bulb and stem vegetables. Putative BFls were identified for spinach, lettuce, endive, asparagus, artichoke, and celery, but not for rocket salad. However, after critical evaluation through a validation scheme developed by the FoodBAll consortium, none of the putative biomarkers appeared to be a promising BFI. The food chemistry data indicate that some candidate BFIs may be revealed by further studies.
\end{abstract}

Conclusion: Future randomized controlled feeding studies combined with observational studies, applying a nontargeted metabolomics approach, are needed in order to identify valuable BFls for the intake of leafy, bulb, and stem vegetables.

Keywords: Lettuce, Spinach, Endive, Garden rocket, Asparagus, Artichoke, Celery

\section{Background}

The importance of an adequate vegetable intake to promote health has been recognized for years. Vegetables are nutrient-dense foods containing high concentrations of dietary fibers as well as various vitamins, minerals, and phytochemicals. Accordingly, the potential impact of vegetable intake on human health has been extensively explored in nutritional epidemiological studies, showing beneficial

\footnotetext{
* Correspondence: elske.brouwer-brolsma@wur.nl

${ }^{\dagger}$ Elske M. Brouwer-Brolsma and Beate Brandl contributed equally to this study.

'Division of Human Nutrition and Health, Wageningen University, PO Box 17, 6700 AA Wageningen, The Netherlands

Full list of author information is available at the end of the article
}

associations [1-3]. Despite these suggested health effects, vegetable consumption rates among European citizens vary substantially, ranging from $34.4 \%$ of the population not consuming fruits and vegetables on a daily basis to $14.1 \%$ eating $\geq 5$ portions [4]. Obviously, the wide variety of available vegetables substantially differs with respect to their nutrient content and associated benefits for health. Therefore, it is crucial to distinguish between the different vegetable groups, e.g., cruciferous vegetables, root vegetables, tubers, fruit vegetables, bulb and stem vegetables, and leafy vegetables, when addressing potential health effects.

Epidemiological data suggest that leafy vegetables deserve special attention. A large meta-analysis including

(c) The Author(s). 2020 Open Access This article is licensed under a Creative Commons Attribution 4.0 International License, which permits use, sharing, adaptation, distribution and reproduction in any medium or format, as long as you give appropriate credit to the original author(s) and the source, provide a link to the Creative Commons licence, and indicate if changes were made. The images or other third party material in this article are included in the article's Creative Commons licence, unless indicated otherwise in a credit line to the material. If material is not included in the article's Creative Commons licence and your intended use is not permitted by statutory regulation or exceeds the permitted use, you will need to obtain permission directly from the copyright holder. To view a copy of this licence, visit http://creativecommons.org/licenses/by/4.0/. 
95 prospective studies recently revealed that a high intake of leafy green vegetables was associated with a reduced risk of coronary heart disease (10 studies, $\mathrm{RR}=$ 0.83, 95\% CI $=0.75-0.91$ ), stroke (4 studies, $R R=0.88$, $95 \% \mathrm{CI}=0.81-0.95)$, and a $24 \%$ reduction in all-cause mortality for each $100 \mathrm{~g} /$ day increment in intake [1]. In another meta-analysis focusing on associations between all fruit and vegetable subtypes and type 2 diabetes, only green leafy vegetables (highest vs lowest intake categories) were associated with a significant risk reduction (RR $=0.84,0.74-0.94$ ) [2]. Spinach (Spinacia oleracea, Amaranthaceae family) represents a main member of leafy vegetables and has been shown to decrease postprandial arterial stiffness and systolic blood pressure in randomized controlled trials [5-7]. Moreover, garden rocket (Eruca sativa), a green-leafy vegetable from the Brassicaceae, has been proposed to possess anti-oxidative, anti-inflammatory, and anti-ulcer properties [8,9]. Asteraceae is another botanical family of leafy vegetables representing amongst others endive and lettuce. Bulb and stem vegetables have been less extensively studied than leafy vegetables and constitute a rather heterogenous group including in particular celery, artichoke and asparagus. Celery (Apium graveolens L.) has been proposed to possess anti-oxidative and anti-inflammatory potency [10, 11], whereas artichoke (Cynara scolymus) received attention through its potential beneficial impact on LDLcholesterol, endothelial NOS expression, and hepatodigestive function [12]. Asparagus (Asparagus officinialis with Asparagales as the botanical family) on its turn is a rich source of asparagine, potassium, vitamin $\mathrm{C}$, and antioxidative glycolipids [13].

Up to now, vegetable intake in the epidemiological studies was generally assessed using traditional selfreported dietary assessment methods, such as food diaries, $24 \mathrm{~h}$ recalls and food frequency questionnaires (FFQs). Although these self-report dietary assessment methods provide valuable information, they are prone to measurement error and burdensome for both participants and researchers. Bingham and colleagues observed that the intake of fruits and vegetables assessed by FFQ was almost 2-fold higher compared with a food diary [14]. At the same time, the association between plasma vitamin $\mathrm{C}$ and the intake of fruits and vegetables was stronger when assessed by food diary than by FFQ, suggesting a higher degree of measurement error with the FFQ than with the food diary [14]. However, the processing of selfadministered FFQs is much more convenient than the handling of diaries or recalls. To get insight in the habitual intake of commonly consumed foods, diaries and $24 \mathrm{~h}$ recalls need to be repeated at least 3 times [15] and even more frequently to capture specific types of vegetables and associated variety-specific nutrients [16]. Therefore, FFQs are usually the method of choice in large observational cohort studies. However, compared to diaries and $24 \mathrm{~h}$ recalls, FFQs are usually more restrained with respect to the variety of foods queried as well as portion size estimations. Moreover, both FFQs and recalls are prone to measurement error resulting from socially desirable answers and errors in food composition tables [1720].

Therefore, the use of candidate biomarkers of food intake (BFIs), i.e., objective food consumption markers in biological specimens such as urine or blood, is gaining interest, even though there are still very few wellvalidated dietary intake biomarkers [21]. The intake of total fruit and vegetable consumption is frequently estimated using blood vitamin $C$ or carotenoids (i.e., plasma $\alpha$ - and $\beta$-carotene, $\beta$-cryptoxanthin, and lutein) $[22,23]$. However, the use of these biomarkers does not allow to distinguish between the types of fruit and vegetables consumed. Integrating the data as obtained by one or more of the traditional dietary assessment methods with validated BFIs data may eventually facilitate nutritional research by resulting in more precise intake estimates that have the ability to distinguish between the specific varieties of fruits and vegetables consumed [24].

To facilitate the identification and evaluation of new candidate BFIs, the Food Biomarker Alliance (FoodBAll) [21], a project funded by the Joint Programming Initiative a Healthy Diet for a Healthy Life, established guidelines to conduct a literature search dedicated to food intake biomarkers [25] and to evaluate their level of validation using a set of consensus criteria [26]. The guidelines were applied for all major food groups: fruit and vegetables, meats, fish, and other marine foods, dairy products, cereals and whole grains, alcoholic and non-alcoholic beverages, vegetable oils, nuts, and spices and herbs (http://foodmetabolome.org/wp3) [27-36]. The present article presents the results of the in depth exploration of possible biomarkers of intake for green leafy vegetables (lettuce, spinach, endive, and garden rocket) as well as bulb and stem vegetables (artichoke, asparagus, celery).

\section{Material and methods Selection of vegetable varieties}

In order to cover the major varieties of vegetables consumed in Europe, FoodBAll aimed to cover cruciferous vegetables, root vegetables, tubers, leafy vegetables, fruit vegetables, and bulb and stem vegetables. In the present review, we focus on the most widely consumed leafy vegetables (lettuce, spinach, endive, garden rocket), and bulb and stem vegetables (asparagus, celery stalk, and artichoke). Herbs such as parsley, dill, basil, or peppermint and leafy cruciferous vegetables such as kale and cabbage are considered in another FoodBAll review in preparation. 


\section{Literature search to identify putative BFls}

To identify relevant studies on leafy vegetables and bulb and stem vegetables, an extensive literature search was conducted following the Biomarker of Food Intake Reviews (BFIRev) methodology as proposed previously [25] built on the PRISMA statement (Preferred Reporting Items for Systematic reviews and Meta-Analyses). Briefly, a primary search was performed in the three databases Scopus, PubMed central, and Web of Science with the name of the specific vegetables and its botanical genus, i.e, (lettuce OR lactuca sativa OR escarole OR frisée), (spinach OR spinacia oleracea), (endive OR cichorium endivia), (garden rocket OR eruca sativa OR rucola OR rocket salad OR arugula OR rucoli OR rugula OR colewort roquette), (asparagus OR asparagus officinalis), (artichoke OR cynara cardunculus OR cynara scolymus), (celery OR apium graveolens) along with the common keywords: AND (urine OR plasma OR serum OR excretion OR blood) AND (human* OR men OR women OR patient* OR volunteer* OR participant*) AND (Biomarker* OR marker* OR metabolite* OR biokinetics OR biotransformation OR bioavailability OR ADME) AND (intake OR meal OR diet OR ingestion OR administration OR consumption OR eating OR drink*). Keywords were used in the fields [Topic], [All fields] and [Article Title/Abstract/Keywords] for Web of Science, PubMed, and Scopus, respectively. All searches were carried out in March 2017 and updated in March 2019. Only papers in English language were considered eligible; no restriction was applied with respect to the publication date. Human observational studies (cohort, case-control, cross-sectional studies) and human intervention studies (randomized controlled trials, acute, short-term, or longterm studies) were considered eligible. After duplicates removal, a first selection of papers was performed according to abstract and title relevance, thereafter fulltext screening was performed.

\section{Evaluation of the identified candidate biomarkers}

The quality of the individual candidate BFIs was assessed by evaluating their plausibility and specificity, dose-response, time-response, robustness, reliability, stability, performance, and reproducibility of their analysis method [26]. The name of the potential biomarkers and their synonyms were queried in the previously mentioned databases in combination with AND (biomarker" OR marker* OR metabolite* OR biokinetics OR biotransformation OR pharmacokinetics OR bioavailability OR ADME) to collect the relevant information for each identified candidate biomarker. In addition, the databases HMDB (https://www.hmdb.ca), FooDB (http:// foodb.ca/), Phenol-Explorer (http://phenol-explorer.eu/), Dictionary of Food Compounds (http://dfc.chemnetbase. com/faces/chemical/ChemicalSearch.xhtml), Duke's phytochemical and ethnobotanical databases (https://phytochem. nal.usda.gov/phytochem/search), eBASIS, (http://ebasis. eurofir.org/Default.asp), Knapsack (http://kanaya.naist.jp/ knapsack_jsp/top.html) and PhytoHub (http://phytohub.eu) were searched to identify all possible sources of each candidate biomarker and thus check its specificity. The validation level of the candidate BFIs was evaluated via the pre-defined criteria set by Dragsted and colleagues [26], which were based on eight questions related to the biological and analytical aspects: Q1: is the marker compound plausible as a specific BFI for the food or food group (chemical/biological plausibility)? Q2: is there a dose-response relationship at relevant intake levels of the targeted food (quantitative aspect)? Q3: is the biomarker kinetics described adequately to make a wise choice of sample type, frequency, and time window (time-response)? Q4: has the marker been shown to be robust after intake of complex meals reflecting dietary habits of the targeted population (robustness)? Q5: has the marker been shown to compare well with other markers or questionnaire data for the same food/food group (reliability)? Q6: is the marker chemically and biologically stable during bio specimen collection and storage, making measurements reliable and feasible? Q7: are analytical variability (CV\%), accuracy, sensitivity, and specificity known as adequate for at least one reported analytical method? Q8: has the analysis been successfully reproduced in another laboratory (reproducibility)? This set of criteria therefore reflects the current level of validation of that particular compound and pinpoints the additional research needed to increase its validation.

\section{Results and discussion} Leafy vegetables

The primary literature search on leafy vegetables resulted in 361 articles. After removal of duplicates, 247 publications were screened based on their title and abstract, 108 publications underwent full-text assessment, and eventually 61 publications were included in this review. In March 2019, the primary literature search was updated. The three databases yielded 34 new hits of which 24 remained after removal of duplicates, ten publications remained after title/abstract screening and four were selected based on the full-text assessment (Fig. 1). Main reasons for exclusion were that the: (1) intake assessment was too general (i.e., vegetable intake), (2) focus was on the effect of the intake on health-related markers, and/or (3) exposure in a nutritional intervention study was not only green leafy vegetables. Finally, the two searches combined resulted in 65 potentially relevant papers that provided data on the intake of one or more of the selected leafy vegetables (lettuce $n=7$, endive $n=1$, rocket salad $n=1$, spinach $n=$ 65) and measured one or more related compounds in body tissue, such as plasma, urine, and/or feces. The main characteristics of these studies are displayed in Additional file 1: Table S1. 


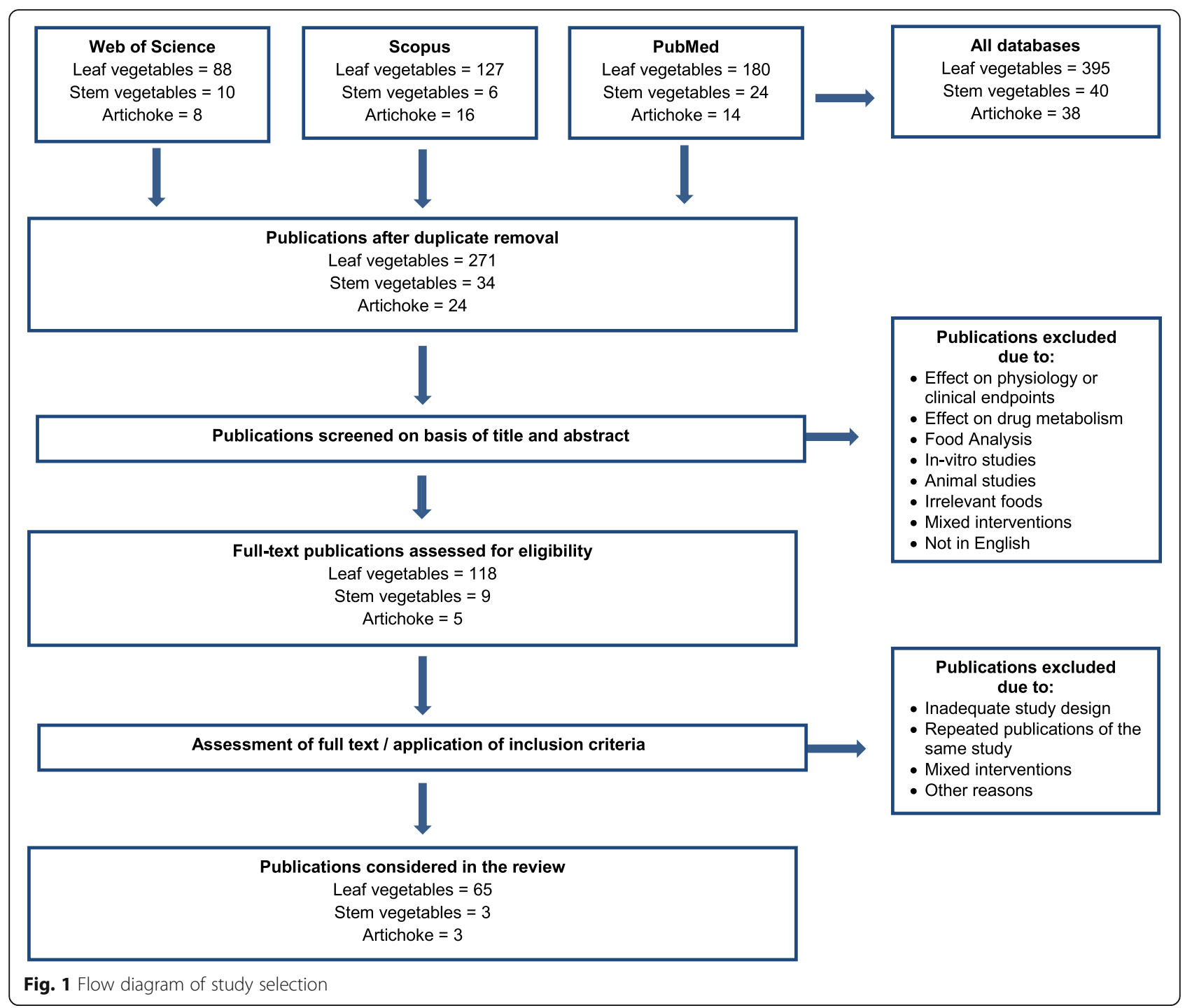

A wide range of metabolites were reported in biofluids after consumption of leafy vegetables. However, as discussed below, many of these metabolites have other dietary origins and were therefore not specific enough to be retained as candidate BFIs. Carotenoids and their derivatives and conjugates were the most commonly reported metabolites after consumption of leafy vegetables. Carotenoids belong to the family of tetraterpenoids; where oxygen-containing carotenoids are called xanthophylls (e.g., lutein and zeaxanthin) and unoxygenated carotenoids are called carotenes (e.g., $\alpha$ - and $\beta$-carotene, and lycopene). As carotenoids are commonly found in a wide range of vegetables, they were considered unspecific and as such not retained as candidate BFIs. To illustrate, a comparative study across five European countries showed that spinach was the food contributing most to the total lutein intake in France, Spain, and the Netherlands (i.e., 30-34\%) [37]. Lettuce was the second major food contributing to lutein intake in France and Spain (i.e., 8-16\%) [37]. However, lutein is also present in egg yolk, pistachio, red pepper, pea, broccoli, corn, and common herbs $[38,39]$. Additionally, spinach has been shown to be a major food contributing to the total $\beta$ carotene intake (12-26\%). Though $\alpha$ - and $\beta$-carotene are primarily obtained through the consumption of carrots [37]. Besides the studies on carotenoids, two observational studies reported that vitamin K1 (phylloquinone) was associated with the consumption of spinach and lettuce $[40$, 41]. However, phylloquinone is widely distributed in all photosynthetic plants, where it serves as a cofactor for photosynthesis and is also available as dietary supplement [42]. Moreover, neither vitamins nor nitrate or phosphate were retained as candidate biomarkers for BFIs as these components are common in a range of other foods as well $[43,44]$. Finally, some intervention studies reported an increased urinary oxalate excretion after consumption of 
spinach. Indeed, it is well-known that spinach should be restricted by individuals at high risk of calcium oxalate kidney stones [45]. However, beetroots, rhubarb, chocolate, wheat bran, almonds, and peanuts are other important sources of oxalic acid, making it not specific enough to represent a promising candidate biomarker of intake for spinach [45].

After excluding articles reporting on obviously nonspecific biomarkers, six articles provided data on candidate BFIs of green leafy vegetables (Table 1). The retained articles included five acute single-dose studies and one cross-over intervention focusing on either urinary and/or blood-based biomarkers (i.e., plasma). Sample sizes were small, ranging from 3 up to 11 participants. Five studies used a targeted approach; one study applied untargeted metabolomics. In total, 9 candidate BFIs were identified for spinach, 2 for lettuce, and 2 for endive. None of the selected articles reported on candidate biomarkers for rocket salad.

\section{Spinach}

Spinach has been considered since ancient times as a food with functional properties that supports health maintenance $[52,53]$. It is of high nutritional value, with large contents of folates, vitamin $\mathrm{A}, \mathrm{C}$, and $\mathrm{K}$, and minerals such as iron, magnesium, and manganese, allowing a substantial contribution to their respective recommended dietary allowances when consuming a single serving [53]. Spinach also provides nitrates that-after conversion by salivary bacteria and host reductases into nitrites-improve the nitric oxide status and as such has been beneficially related to vascular function and blood pressure $[6,7]$. Spinach also contains a number of phytochemicals, including chlorophylls, carotenoids (lutein, neoxanthin, zeaxanthin), and chloroplast-specific lipids, e.g., mono- and di-galactosyldiacylglycerol (MGDG and DGDG, respectively) and the anionic sulfolipid, sulfoquinovosediacylglycerol (SQDG). It also provides unique flavonoids, e.g., derivatives of patuletin, spinacetin, spinatoside, jaceidin, and methylenedioxyflavone [54-56].

Of the four identified studies that examined changes in metabolites associated with spinach intake, none had the objective to identify BFI (Table 1). Although it is generally assumed that chlorophyll derivatives have very low bioavailability [57], Chao and colleagues (2018) reported on the identification of chlorophyll-related compounds, i.e., pheophytin (FDB007170) and pheophorbide (FDB031104) derivatives, in plasma $3 \mathrm{~h}$ following a high acute dose of just-boiled fresh spinach [46]. Pheophytin and pheophorbide are degradation products of chlorophylls that lack the central $\mathrm{Mg}^{2+}$ ion and are readily produced during thermal processing or acidification [57]. It is commonly known that chlorophylls and derivatives are ubiquitous in all photosynthetic plants with particularly high levels in leafy green vegetables. Chlorophylls and derivatives are thus unlikely to be sufficiently specific for spinach, even when used in combination with other spinach derived compounds [58].

A pilot metabolomic study explored the changes in the urine metabolomes of 10 participants after an acute intake of $200 \mathrm{~g}$ spinach in the context of a controlled diet, compared to the intake of $200 \mathrm{~g}$ celery, $200 \mathrm{~g}$ onion, or to the controlled diet without addition of any vegetable [47]. The principal component analysis score plot showed a shift in the post-spinach urine metabolome compared to the control group and intake of other vegetables. However, among the signals discriminating spinach intake, the authors only reported one discriminating ion with $\mathrm{m} / \mathrm{z} 214.15$ that was tentatively identified as 4guanidino-butanoic acid with an isoprene modification. When the identification is confirmed, the validation criteria proposed by the FoodBAll consortium BFI will have to be assessed for this compound. Similar intervention studies using untargeted metabolomics with large analytical coverage will be of great value to identify other candidate biomarkers of spinach intake, provided that the discriminating signals can be properly identified.

Another selected study was a cross-over intervention with 3 weeks supplementation that aimed at comparing the effects of spinach and cheese on the calcium and zinc balance, oxalate excretion, and urinary hydroxyproline in 7 post-menopausal women [48]. An increased urinary excretion of hydroxyproline (PubChem CID: 5810) was reported. However, this compound is a common amino acid and a constituent of collagen that has also been suggested as a biomarker for processed meat consumption and can therefore be excluded as candidate biomarker for spinach [59].

The last relevant study aimed at identifying the polyphenol metabolites recovered in human plasma after ingestion of $5 \mathrm{~g}$ freeze-dried ${ }^{13} \mathrm{C}$-labeled spinach. The main metabolites were a glucuronide and a sulfate of 5,3',4'-trihydroxy3-methoxy-6,7-methylendioxyflavone (TMM), and spinacetin-glucuronide-sulfate [49]. The secondary search in the literature and in various databases (FooDB, PhytoHub, Duke's phytochemical and ethnobotanical database, Phenol-Explorer, CRC press Dictionary of Food Compounds) revealed that the derivatives of spinacetin and TMM are compounds with a high specificity for spinach. As specificity is an important prerequisite for BFIs, the metabolites of spinacetin and TMM identified in plasma deserve further investigation as putative intake biomarkers, with the examination of the other validation criteria. Such derivatives of the spinach flavonoids are likely to be also present in urine samples. However, they were not targeted in the analyses conducted on urine samples so far.

Thus, the available literature is scarce on putative BFIs for spinach. However, a few studies as well as the 
Table 1 Overview of the selected studies on green-leafy vegetables

\begin{tabular}{|c|c|c|c|c|c|c|c|c|}
\hline $\begin{array}{l}\text { Dietary } \\
\text { factor }\end{array}$ & Intervention & $\begin{array}{l}\text { Dose of } \\
\text { intervention }\end{array}$ & Study design & $n$ & Analytical method & $\begin{array}{l}\text { Sample } \\
\text { type }\end{array}$ & $\begin{array}{l}\text { Candidate biomarkers of food } \\
\text { intake }\end{array}$ & $\begin{array}{l}\text { Primary } \\
\text { reference }\end{array}$ \\
\hline \multicolumn{9}{|l|}{ Spinach } \\
\hline & $\begin{array}{l}\text { Just-boiled } \\
\text { fresh } \\
\text { spinach }\end{array}$ & $1.2 \mathrm{~kg}$ & $\begin{array}{l}\text { Acute single } \\
\text { dose }\end{array}$ & 8 & HPLC-UV & $\begin{array}{l}\text { Plasma } \\
\text { (after } 3 \\
\text { h) }\end{array}$ & $\begin{array}{l}\text { Chlorophyll-related compounds } \\
\text { (CRCs) (pheophytin (Phe) and } \\
\text { pheophorbide (Pho)) }\end{array}$ & [46] \\
\hline & $\begin{array}{l}\text { Vegetable } \\
\text { together } \\
\text { with fried } \\
\text { rice }\end{array}$ & $200 \mathrm{~g}$ & $\begin{array}{l}\text { First study: } \\
\text { acute single } \\
\text { doses (4 distinct } \\
\text { treatments: } \\
\text { spinach, celery, } \\
\text { onion, no } \\
\text { vegetables) } \\
\text { Second/third } \\
\text { studies } \\
\text { confirmation: } \\
\text { singles doses or } \\
\text { combinations }\end{array}$ & $\begin{array}{l}10 \text { (and } 3 \\
\text { for } \\
\text { secondand } \\
\text { third) }\end{array}$ & $\begin{array}{l}\text { LC-MS (UPLC and } \\
\text { Q-TOF MS) (untar- } \\
\text { geted } \\
\text { metabolomics) }\end{array}$ & $\begin{array}{l}\text { Urine } \\
\text { (up to } 7 \\
\text { h) }\end{array}$ & $\begin{array}{l}\text { 4-guanidino-butanoic acid with } \\
\text { an Isoprene modification } \\
\text { (tentative identification) }\end{array}$ & [47] \\
\hline & $\begin{array}{l}\text { Spinach- } \\
\text { containing } \\
\text { diet-frozen } \\
\text { spinach } \\
\text { thawed and } \\
\text { cooked }\end{array}$ & 453 g spinach/day & $\begin{array}{l}\text { 2-arm cross- } \\
\text { over interven- } \\
\text { tion }(2 \times 3 \\
\text { weeks })\end{array}$ & 7 & $\begin{array}{l}\text { Atomic absorption } \\
\text { spectrophotometry } \\
\text { (Faecal, urinary, and } \\
\text { dietary calcium and } \\
\text { zinc levels) } \\
\text { kits for oxalate and } \\
\text { hydroxyproline- } \\
\text { assays }\end{array}$ & Urine & Hydroxyproline & [48] \\
\hline & $\begin{array}{l}\text { Freeze- } \\
\text { dried }{ }^{13} \mathrm{C}- \\
\text { labeled } \\
\text { spinach }\end{array}$ & $\begin{array}{l}5 \mathrm{~g} \text { (providing } 160 \\
\mu \mathrm{mol} \\
\text { methoxyflavonols, } \\
\text { including } 70 \text { } \mathrm{mol} \\
\text { TMM4'- } \\
\text { glucuronide) }\end{array}$ & $\begin{array}{l}\text { Acute single } \\
\text { dose }\end{array}$ & 5 & UHPLC-MS ${ }^{n}$ & $\begin{array}{l}\text { Plasma } \\
\text { (up to } \\
24 \text { h) }\end{array}$ & $\begin{array}{l}{ }^{13} \mathrm{C}_{17} \mathrm{TMM} \text {-glucuronide } \\
{ }^{13} \mathrm{C}_{17} \mathrm{TMM} \text {-sulfate } \\
{ }^{13} \mathrm{C}_{16} \text { Patuletin- } \\
\text { glucuronidesulfate-methyl } \\
{ }^{12} \mathrm{C}_{1}^{13} \mathrm{C}_{16} \text { Spinacetinglucuronide- } \\
\text { sulfate } \\
{ }^{13} \mathrm{C}_{17} \text { Spinacetinglucuronide- } \\
\text { sulfate }\end{array}$ & [49] \\
\hline \multicolumn{9}{|l|}{ Lettuce } \\
\hline & $\begin{array}{l}\text { Fresh } \\
\text { lettuce }\end{array}$ & $250 \mathrm{~g}$ & $\begin{array}{l}\text { Acute single } \\
\text { dose }\end{array}$ & 11 & HPLC-Coularray & $\begin{array}{l}\text { Plasma } \\
\text { (up to } 6 \\
\text { h) }\end{array}$ & $\begin{array}{l}\rho \text {-coumaric acid } \\
\text { Caffeic acid }\end{array}$ & [50] \\
\hline \multicolumn{9}{|l|}{ Endive } \\
\hline & $\begin{array}{l}\text { Endive } \\
\text { soup ( } 300 \\
\text { g) with a } \\
\text { slice of } \\
\text { white bread }\end{array}$ & $\begin{array}{l}150 \mathrm{~g} \text { (precooked } \\
\text { mass) of endive = } \\
9 \mathrm{mg} \text { kaempferol }\end{array}$ & $\begin{array}{l}\text { Acute single } \\
\text { dose }\end{array}$ & 8 & LC/MS & $\begin{array}{l}\text { plasma } \\
\text { and } \\
\text { urine } \\
\text { (up to } \\
24 \text { h) }\end{array}$ & $\begin{array}{l}\text { Kaempferol-3-glucoside } \\
\text { Kaempferol-3-glucuronide }\end{array}$ & [51] \\
\hline
\end{tabular}

specific phytochemical composition of spinach suggest that further studies designed for identification of BFIs and using an exploratory metabolomic approach should reveal specific candidate biomarkers for this leafy vegetable. As spinach can be consumed either in raw (salads, smoothies) or cooked forms (steamed, boiled, pan-fried, in soups), it will be of interest to assess the performance of the candidate BFIs for the various forms consumed.

\section{Lettuce and endive}

Lettuce and endive (Asteraceae family) are leafy vegetables with a rich nutrient profile that is rather comparable to spinach (Amaranthaceae family). The presence of sesquiterpene lactones in lettuce and endive is what sets the two species apart, which is immediately noticed when consuming the vegetables owing to their bitter taste [60, 61]. Lactucin, lactucopicrin, 8-deoxylactucopicrin, lettucenin A, and lactuside $\mathrm{A}$ are the main sesquiterpene lactones reported in lettuce and endive [61]. However, the presence of these compounds and their metabolites in human biofluids and their possible usefulness as biomarkers of intake have not been considered so far.

We identified only one article that examined metabolite changes after lettuce intake (Table 1), which detected $\rho$-coumaric acid (PubChem CID: 637542) and caffeic acid (PubChem CID: 689043) in plasma $6 \mathrm{~h}$ following an acute single dose of lettuce [50]. However, $\rho$-coumaric acid is also present in many other foods, ranging from 
fruits (e.g., apples, oranges, grapes, berries), vegetables (e.g., beans, potatoes, onions) to cereals (e.g., maize, oats, and wheat) [62]. As reported based on the Bavarian Food Consumption Survey (Germany), caffeic acid is mainly obtained through the intake of coffee (92\%) followed by fruit consumption [63]. Both caffeic and pcoumaric acid have a too broad distribution in food to be used as BFIs, even in combination with other compounds. The only potentially relevant article for endive reported on the identification of kaempferol-3glucoside (PubChem CID: 5282102) and kaempferol3-glucuronide (PubChem CID: 22846027) in urine and plasma following a single dose of $300 \mathrm{~g}$ thick endive soup consumed with a slice of white bread and a glass of water (Table 1) [51]. Once more, these compounds are also present in a wide variety of other plants [64]. According to Phenol-Explorer, kaempferol and its glucoside have been reported in high content in many herbs and spices, in tea, common beans, in kale and other cruciferous vegetables, as well as in Swiss chard leaves and in spinach.

Thus, eventually, none of the compounds resulting from the systematic search for green leafy vegetables were sufficiently promising to be evaluated on the validation criteria. Yet, metabolites of sesquiterpene lactones may deserve further study as putative BFIs.

\section{Bulb and stem vegetables}

The literature search in the three databases resulted in 40 papers considering asparagus or celery and 38 papers considering artichoke. Most papers reported on health effects rather than on candidate biomarkers of intake, used in vitro and animal models, and particularly focused on immune-modulation upon different asparaguspreparations. As such, these studies did not match our inclusion criteria and were excluded. After removal of duplicates, title/abstract screening, and full-text screening, eventually six papers were considered relevant for this review (asparagus $(n=2)$, artichoke $(n=3)$, and celery $(n=1))$ (Table 2$)$.

\section{Asparagus}

Asparagus spears (Asparagus officinalis with Asparagales as the botanical family) are frequently consumed in various areas throughout Europe and asparagus preparations have been considered to exhibit distinct health effects $[13,71]$. Due to these suggested health effects, the refined taste of Asparagus, and the odorant urine associated with its consumption, the ingredients of Asparagus are matter of intense investigation [72]. More than 100 of volatile compounds have been detected in asparagus, as well as rutin, a glycoside of the widely distributed quercetin, and glutathione in high content [73].

Table 2 Overview of the selected studies on bulb-and stem vegetables

\begin{tabular}{|c|c|c|c|c|c|c|c|c|}
\hline $\begin{array}{l}\text { Dietary } \\
\text { factor }\end{array}$ & Intervention & $\begin{array}{l}\text { Dose of } \\
\text { intervention }\end{array}$ & Study design & $n$ & $\begin{array}{l}\text { Analytical } \\
\text { method }\end{array}$ & Sample type & $\begin{array}{l}\text { Candidate biomarkers } \\
\text { of food intake }\end{array}$ & $\begin{array}{l}\text { Primary } \\
\text { reference }\end{array}$ \\
\hline \multirow[t]{2}{*}{ Asparagus } & $\begin{array}{l}\text { Freshly boiled } \\
\text { Asparagus }\end{array}$ & $100 \mathrm{~g}$ & $\begin{array}{l}\text { Acute intervention (single } \\
\text { dose intervention) }\end{array}$ & 8 & GC-MS & Urine & $\begin{array}{l}\text { S-methyl-thioacrylate } \\
\text { S-methyl-3- } \\
\text { (methylthio)- } \\
\text { thiopropionate } \\
\text { Dimethyl trisulfide } \\
\text { Tetrahydrothiophene }\end{array}$ & [65] \\
\hline & Asparagus & $500 \mathrm{~g}$ & $\begin{array}{l}\text { Acute intervention } \\
\text { (single dose intervention) } \\
\text { Repetition three months } \\
\text { later }\end{array}$ & $\begin{array}{l}8 \\
3\end{array}$ & GC-MS & $\begin{array}{l}\text { Urine (overnight } \\
\text { collection after } \\
\text { asparagus dinner) }\end{array}$ & $\begin{array}{l}\text { Methanethiol, } \\
\text { Dimethyl sulphide } \\
\text { Dimethyl disulphide } \\
\text { Bis- } \\
\text { (methylthio)methane } \\
\text { Dimethyl sulphoxide } \\
\text { Dimethyl sulphone }\end{array}$ & [66] \\
\hline \multirow[t]{3}{*}{ Artichoke } & $\begin{array}{l}\text { Steam cooked } \\
\text { artichoke }\end{array}$ & $\begin{array}{l}61.7 \mathrm{~g} \text { with } 5.5 \\
\mathrm{~g} \text { olive oil }\end{array}$ & $\begin{array}{l}\text { Acute intervention } \\
\text { (single dose intervention) }\end{array}$ & 5 & $\begin{array}{l}\text { HPLC- } \\
\text { Coularray }\end{array}$ & $\begin{array}{l}\text { Plasma (7 consecutive } \\
\text { samples during } 8 \text { h) }\end{array}$ & $\begin{array}{l}\text { Hydroxycinnamic } \\
\text { acid } \\
\text { Dicaffeoylquinic acid }\end{array}$ & [67] \\
\hline & $\begin{array}{l}\text { Artichoke } \\
\text { capsules }\end{array}$ & 320 mg extracts & $\begin{array}{l}\text { Acute intervention } \\
\text { ( } 3 \text { doses during } 8 \text { hours, } \\
0,4 \text { and } 8 \text { hours) }\end{array}$ & 10 & HPLC & $\begin{array}{l}\text { Urine ( } 24 \mathrm{~h} \text { urine vs. } \\
\text { baseline) }\end{array}$ & $\begin{array}{l}\text { Ferulic acid } \\
\text { Isoferulic acid } \\
\text { Dihydroferulic acid } \\
\text { Vanilic acid }\end{array}$ & [68] \\
\hline & $\begin{array}{l}\text { Artichoke leaf } \\
\text { extract (ALE) }\end{array}$ & $\begin{array}{l}2 \text { different high- } \\
\text { dose artichoke } \\
\text { leaf extracts - } \\
\text { (ALE): } \\
\text { ALE A } 2.4 \mathrm{~g} \text { and } \\
\text { ALE B } 0.625 \mathrm{~g}\end{array}$ & $\begin{array}{l}\text { Acute intervention ( } 2 \\
\text { different doses, cross-over, } \\
\text { separated by } 10 \text { days } \\
\text { wash out }\end{array}$ & 14 & HPLC & $\begin{array}{l}\text { Blood and urine } \\
\text { (13 blood samples over } \\
12 \mathrm{~h}, 1 \text { urine sample } \\
\text { after } 24 \mathrm{~h} \text { ) }\end{array}$ & $\begin{array}{l}\text { Caffeoylquninic acid } \\
\text { Dihydroferulic acid } \\
\text { Ferulic acid } \\
\text { Dihydrocaffeic acid }\end{array}$ & [69] \\
\hline Celery & Celery leaves & $\begin{array}{l}2 \mathrm{~g} / \mathrm{kg} \text { body } \\
\text { weight }\end{array}$ & $\begin{array}{l}\text { Controlled acute Study } \\
\text { (single dose intervention) }\end{array}$ & 20 & HPLC & $\begin{array}{l}\text { Plasma (9 samples over } \\
28 \mathrm{~h}\end{array}$ & Apigenin & [70] \\
\hline
\end{tabular}


Asparagus is a rich source of asparagine, potassium, and vitamin C. Two compounds seem specific for asparagus, specifically asparagusic acid [73, 74], a heterocyclic compound with two sulphur atoms, and the saponin protodioscin that is only present in fenugreek in the human diet. Documentation of potential biomarkers is sparse. From the literature screening only two papers were retained for this review.

White and colleagues used GC-MS to identify the odor-bearing compounds in urine samples of 8 participants, after the intake of $100 \mathrm{~g}$ asparagus freshly boiled for $10 \mathrm{~min}$, and reported on the identification of $\mathrm{S}$ methyl-thioacrylate (also known as 2-propenethioic acid, PubChem CID: 543202), S-methyl-3-(methylthio)-thiopropionate, tetrahydrothiophene, and dimethyl trisulfide [65]. Moreover, Waring and colleagues provided $500 \mathrm{~g}$ asparagus spears to 8 participants and identified six sulphur-containing alkyl compounds identified as methanethiol, dimethyl sulphide, dimethyl disulphide, bis-(methylthio)methane, dimethyl sulphoxide, and dimethyl sulphone in overnight urine samples following asparagus dinner [66]. Consumption of asparagus is known from ancient times to cause odorous urine, often described as rotten cabbage-like. However, the interindividual variation for the production of odorous urinary metabolites after asparagus intake has been intriguing for centuries and is not yet fully elucidated. We now know that apart from differences in the production of odorous metabolites, some individuals are unable to smell the asparagus-associated odor in urine, due to a specific anosmia related to genetic polymorphisms near the olfactory receptor gene OR2M7. In a well-controlled study taking into account anosmia, $92 \%$ of the 37 volunteers produced odorous urine, although with differences in intensity [75].

In conclusion, while odorous urine is frequently recognizable after asparagus consumption likely due to highly volatile metabolites of asparagusic acid [66], these metabolites may not represent appropriate quantitative BFIs because of the inter-individual variation in their production. So far, all research was performed with GC-MS on urine samples. Other non-volatile metabolites specific for asparagus may be identified with LC-MS, possibly in plasma as well.

\section{Celery stalks}

Celery stalks (Apium graveolens L.) from the family of Apiaceae / Umbelliferae have a Mediterranean origin and are often used for flavoring as food or as extract. Their biological effects have been little studied so far [10]. Regarding celery, seven publications were screened on basis of title and abstract, of which one paper reported on a potential candidate BFI for celery, namely, apigenin [70]. Apigenin belong to the flavone family and its content is reported to be $1.3-10.8 \mathrm{mg} / 100 \mathrm{~g}$ fresh celery (Apium graveolens var. dulce) [76]. However, apigenin is not unique to celery. It is also present in high amount in parsley and Chamomile, and distributed in many other foods in lower concentrations [76]. There is still too little information about the bioavailability of apigenin after consumption of its different sources, its metabolism, pharmaco-kinetics, and dose-response, to state whether apigenin might be useful as a component of a combined BFI for celery.

\section{Artichoke}

Artichoke (Cynara scolymus), from the family of Asteraceae, has been used for centuries as food and herbal medicine, already by the ancient Egyptians, Greeks, and Romans who considered it as a digestive aid and a treatment for hepato-digestive diseases [77]. It has more recently received substantial attention for its potential beneficial effects on dyslipidemia, e.g., lowering blood LDL-cholesterol and triglycerides [78], stimulation of bile secretion, prebiotic effects, upregulation of endothelial NOS expression [12], and for its hepato-protective effects [79]. These health benefits have been attributed to the synergy between inulin, a soluble fiber of the fructans family and polyphenols such as cynarin (1,3-Odicaffeoylquinic acid; HMDB0029279), chlorogenic acid, and luteolin glycosides [77, 79]. Artichoke leaves extracts are also consumed as herbal supplement and many of the published studies were conducted using such supplements. Of the 38 retrieved publications for artichoke, three were included in this review. All of these were acute intervention studies with 5-14 volunteers. Whereas Azzini et al. used cooked vegetable $(61.7 \mathrm{~g}$ administered in a single dose) [67], Rechner used capsules with $320 \mathrm{mg}$ extracts in three doses during $8 \mathrm{~h} \mathrm{[68]} \mathrm{and}$ Wittemer used high-dose leaf extracts with standardized flavonoid content [69] (Table 2). These publications reported on hydroxycinnamic acid [67], dicaffeoylquinic acid [68], caffeoylquinic acid, and dihydroferulic acid [69], which were either measured in plasma (Azzini), urine (Rechner), or both (Wittemer). As these components are identified after consumption of many other food items as well (e.g., plum, coffee beverages), none of these compounds can therefore be followed up a specific $\mathrm{BFI}$, even for used in combined BFI.

\section{The way forward}

Based on the identified studies in this literature review it is clear that there is a need for new intervention studies with well-controlled experimental diets to successfully identify potential BFIs for lettuce, spinach, endive, garden rocket, asparagus, celery, and artichoke. In particular, studies applying untargeted analyses with large analytical coverage are warranted. All the studies identified in this review, except one, used a targeted approach. Targeted analyses have a great selectivity and sensitivity, but only 
assess a limited number of known metabolites. Untargeted analyses measure hundreds of metabolites at once in an exploratory manner and therefore provide a more effective route to detect potential interesting new candidate BFIs when our knowledge is too limited. A combination of two or more of the metabolites identified with untargeted analyses, instead of a single biomarker is a promising approach to establish more specific and robust BFIs for lettuce, spinach, endive, garden rocket, asparagus, celery, and artichoke. Observational studies with precise data on dietary intake as well as biological samples are needed as a second step to assess the specificity and robustness of the candidate BFIs. Possible confounding factors can only be identified in large free-living populations eating complex non-controlled diets and it is preferable to assess the applicability of the candidate BFIs in several populations with different dietary background [80-82].

\section{Conclusions}

The extensive literature search conducted under the well-defined criteria of the BFIRev protocol demonstrated that the field has only been poorly studied so far and that there are no specific candidates BFIs for leafy vegetables yet. However, the food chemistry data indicate that some fairly specific compounds exist for the vegetables under study. Future well-designed studies, including randomized controlled feeding studies as well as observational studies, applying an untargeted metabolomics approach, may thus yield new candidate BFIs for the intake of green leafy vegetables.

\section{Supplementary information}

Supplementary information accompanies this paper at https://doi.org/10. 1186/s12263-020-00667-z.

Additional file 1:. Table S1. Overview of all potentially relevant studies on green leafy vegetables [6, 40, 41, 46-49, 51, 83-144]

\section{Authors' contributions}

This manuscript was drafted by EMBB, BB, MB, TS, and CM. All authors critically commented on the manuscript. All authors read and approved the final version.

\section{Funding}

This work was financially support by the EU Joint Programming Initiative "A Healthy Diet for a Healthy Life" on Biomarkers BioNH FOODBALL (grant number 529051002); the German Federal Ministry of Food and Agriculture (BMEL) through the Federal Office for Agriculture and Food (BLE) (grant numbers 2814ERA01E, 2814ERA02E, 2814ERA03E); the Canadian Institutes of Health Research (CIHR); the Spanish National Grants from the Ministry of Economy and Competitiveness (MINECO) (PCIN-2014-133-MINECO Spain), the Generalitat de Catalunya's Agency AGAUR (2014SGR1566); the Research Foundation Flanders (grant number G0D4615N); the Agence Nationale de la Recherche (\#ANR-14-HDHL-0002-02); the Italian Ministry of Agriculture, Food and Forestry Policies (MiPAAF) within the JPI-HDHL (MIUR D.M. 115/2013); the Swiss National Science Foundation (40HD40_160618) in the frame of the national research program "Healthy nutrition and sustainable food protection" (NRP69)"; the Danish Innovation Foundation (4203-00002B); the Science Foundation Ireland (SFI 14/JPI-HDHL/B3076 and SFI 11/PI/1119), and the Norwegian Research Council (246413 JPI HDHL: The Food Biomarkers Alliance).
Availability of data and materials

Not applicable.

Ethics approval and consent to participate

Not applicable.

Consent for publication

Not applicable.

\section{Competing interests}

The authors declare that they have no competing interests.

\section{Author details}

'Division of Human Nutrition and Health, Wageningen University, PO Box 17, 6700 AA Wageningen, The Netherlands. 'ZIEL Institute for Food and Health, Core Facility Human Studies, Technical University of Munich, Freising, Germany. ${ }^{3}$ Else Kroener-Fresenius Center of Nutritional Medicine, Technical University of Munich, Freising, Germany. ${ }^{4}$ Université Clermont Auvergne, INRA, UMR1019, Human Nutrition Unit, F63000 Clermont-Ferrand, France.

Received: 12 November 2019 Accepted: 27 March 2020

Published online: 09 April 2020

\section{References}

1. Aune D, Giovannucci E, Boffetta P, Fadnes LT, Keum N, Norat T, et al. Fruit and vegetable intake and the risk of cardiovascular disease, total cancer and all-cause mortality-a systematic review and dose-response meta-analysis of prospective studies. Int J Epidemiol. 2017;46(3):1029-56.

2. Cooper AJ, Forouhi NG, Ye Z, Buijsse B, Arriola L, Balkau B, et al. Fruit and vegetable intake and type 2 diabetes: EPIC-InterAct prospective study and meta-analysis. Eur J Clin Nutr. 2012;66(10):1082-92.

3. Wang X, Ouyang Y, Liu J, Zhu M, Zhao G, Bao W, et al. Fruit and vegetable consumption and mortality from all causes, cardiovascular disease, and cancer: systematic review and dose-response meta-analysis of prospective cohort studies. BMJ. 2014;349:g4490.

4. Eurostat Statistics Explained. Fruit and vegetable consumption statistics 2018 [Available from: https://ec.europa.eu/eurostat/statistics-explained/ index.php/Fruit_and_vegetable_consumption_statistics.

5. Jovanovski E, Bosco L, Khan K, Au-Yeung F, Ho H, Zurbau A, et al. Effect of spinach, a high dietary nitrate source, on arterial stiffness and related hemodynamic measures: a randomized, controlled trial in healthy adults. Clin Nutr Res. 2015;4(3):160-7.

6. Liu AH, Bondonno CP, Croft KD, Puddey IB, Woodman RJ, Rich L, et al. Effects of a nitrate-rich meal on arterial stiffness and blood pressure in healthy volunteers. Nitric Oxide. 2013:35:123-30.

7. Bondonno CP, Yang X, Croft KD, Considine MJ, Ward NC, Rich L, et al. Flavonoid-rich apples and nitrate-rich spinach augment nitric oxide status and improve endothelial function in healthy men and women: a randomized controlled trial. Free Rad Biol Med. 2012;52(1):95-102.

8. Villatoro-Pulido M, Font R, Saha S, Obregon-Cano S, Anter J, Munoz-Serrano A, et al. In vivo biological activity of rocket extracts (Eruca vesicaria subsp. sativa (miller) Thell) and sulforaphane. Food Chem Toxicol. 2012;50(5):138492.

9. Alqasoumi S, Al-Sohaibani M, Al-Howiriny T, Al-Yahya M, Rafatullah S. Rocket "Eruca sativa": a salad herb with potential gastric anti-ulcer activity. World J Gastroenterol. 2009;15(16):1958-65.

10. Kooti W, Daraei N. A review of the antioxidant activity of celery ( Apium graveolens L). J Evid Based Complementary Altern Med. 2017;22(4):1029-34.

11. Maljaei MB, Moosavian SP, Mirmosayyeb O, Rouhani MH, Namjoo I, Bahreini A. Effect of celery extract on thyroid function; is herbal therapy safe in obesity? Int J Prev Med. 2019;10:55.

12. Li H, Xia N, Brausch I, Yao Y, Forstermann U. Flavonoids from artichoke (Cynara scolymus L.) up-regulate endothelial-type nitric-oxide synthase gene expression in human endothelial cells. J Pharmacol Experiment Therapeutics. 2004:310(3):926-32.

13. Sugawara T, Miyazawa T. Separation and determination of glycolipids from edible plant sources by high-performance liquid chromatography and evaporative light-scattering detection. Lipids. 1999;34(11):1231-7.

14. Bingham $\mathrm{S}$, Luben $\mathrm{R}$, Welch $\mathrm{A}$, Low $\mathrm{YL}$, Khaw $\mathrm{KT}$, Wareham $\mathrm{N}$, et al. Associations between dietary methods and biomarkers, and between fruits 
and vegetables and risk of ischaemic heart disease, in the EPIC Norfolk cohort study. Int J Epidemiol. 2008:37(5):978-87.

15. Beaton GH, Milner J, McGuire V, Feather TE, Little JA. Source of variance in 24-hour dietary recall data: implications for nutrition study design and interpretation. Carbohydrate sources, vitamins, and minerals. Am J Clin Nutr. 1983;37(6):986-95.

16. Willet W. Nutritional epidemiology. 2nd ed. New York: Oxford University Press; 1998

17. Braam LA, Ocke MC, Bueno-de-Mesquita HB, Seidell JC. Determinants of obesity-related underreporting of energy intake. Am J Epidemiol. 1998; 147(11):1081-6.

18. Cade J, Thompson R, Burley V, Warm D. Development, validation and utilisation of food-frequency questionnaires - a review. Public Health Nutr. 2002;5(4):567-87.

19. Freedman LS, Schatzkin A, Midthune D, Kipnis V. Dealing with dietary measurement error in nutritional cohort studies. J Natl Cancer Institute. 2011;103(14):1086-92.

20. Johansson L, Solvoll K, Bjorneboe GE, Drevon CA. Under- and overreporting of energy intake related to weight status and lifestyle in a nationwide sample. Am J Clin Nutr. 1998;68(2):266-74.

21. Brouwer-Brolsma EM, Brennan L, Drevon CA, van Kranen H, Manach C, Dragsted LO, et al. Combining traditional dietary assessment methods with novel metabolomics techniques: present efforts by the food biomarker Alliance. Proc Nutr Soc. 2017;76(4):619-27.

22. Couillard C, Lemieux S, Vohl MC, Couture P, Lamarche B. Carotenoids as biomarkers of fruit and vegetable intake in men and women. $\mathrm{Br} J$ Nutr. 2016;116(7):1206-15.

23. Baldrick FR, Woodside JV, Elborn JS, Young IS, McKinley MC. Biomarkers of fruit and vegetable intake in human intervention studies: a systematic review. Crit Rev Food Sci Nutr. 2011;51(9):795-815.

24. Jenab M, Slimani N, Bictash M, Ferrari P, Bingham SA. Biomarkers in nutritional epidemiology: applications, needs and new horizons. Human Genet. 2009;125(5-6):507-25.

25. Pratico G, Gao Q, Scalbert A, Vergeres G, Kolehmainen M, Manach C, et al. Guidelines for biomarker of food intake reviews (BFIRev): how to conduct an extensive literature search for biomarker of food intake discovery. Genes Nutr. 2018;13:3.

26. Dragsted LO, Gao Q, Scalbert A, Vergeres G, Kolehmainen M, Manach C, et al. Validation of biomarkers of food intake-critical assessment of candidate biomarkers. Genes Nutr. 2018;13:14.

27. Dragsted LO, Gao Q, Pratico G, Manach C, Wishart DS, Scalbert A, et al. Dietary and health biomarkers-time for an update. Genes Nutr. 2017;12:24.

28. Ulaszewska M, Vazquez-Manjarrez N, Garcia-Aloy M, Llorach R, Mattivi F, Dragsted LO, et al. Food intake biomarkers for apple, pear, and stone fruit. Genes Nutr. 2018;13:29.

29. Munger LH, Garcia-Aloy M, Vazquez-Fresno R, Gille D, Rosana ARR, Passerini $A$, et al. Biomarker of food intake for assessing the consumption of dairy and egg products. Genes Nutr. 2018;13:26.

30. Rothwell JA, Madrid-Gambin F, Garcia-Aloy M, Andres-Lacueva C, Logue C, Gallagher AM, et al. Biomarkers of intake for coffee, tea, and sweetened beverages. Genes Nutr. 2018;13:15.

31. Sri Harsha PSC, Wahab RA, Garcia-Aloy M, Madrid-Gambin F, Estruel-Amades S, Watzl B, et al. Biomarkers of legume intake in human intervention and observational studies: a systematic review. Genes Nutr. 2018;13:25

32. Pratico G, Gao Q, Manach C, Dragsted LO. Biomarkers of food intake for allium vegetables. Genes Nutr. 2018;13:34

33. Garcia-Aloy M, Hulshof PJM, Estruel-Amades S, Oste MCJ, Lankinen M, Geleijnse JM, et al. Biomarkers of food intake for nuts and vegetable oils: an extensive literature search. Genes Nutr. 2019;14:7.

34. Zhou X, Gao Q, Pratico G, Chen J, Dragsted LO. Biomarkers of tuber intake. Genes Nutr. 2019;14:9.

35. Vazquez-Fresno R, Rosana ARR, Sajed T, Onookome-Okome T, Wishart NA, Wishart DS. Herbs and spices- biomarkers of intake based on human intervention studies - a systematic review. Genes Nutr. 2019;14:18.

36. Michielsen C, Almanza-Aguilera E, Brouwer-Brolsma EM, Urpi-Sarda M, Afman LA. Biomarkers of food intake for cocoa and liquorice (products): a systematic review. Genes Nutr. 2018;13:22.

37. O'Neill ME, Carroll Y, Corridan B, Olmedilla B, Granado F, Blanco I, et al. A European carotenoid database to assess carotenoid intakes and its use in a five-country comparative study. Br J Nutr. 2001;85(4):499-507.

38. Maiani G, Caston MJ, Catasta G, Toti E, Cambrodon IG, Bysted A, et al. Carotenoids: actual knowledge on food sources, intakes, stability and bioavailability and their protective role in humans. Mol Nutr Food Res. 2009; 53(Suppl 2):S194-218.

39. Abdel-Aal el SM, Akhtar H, Zaheer K, Ali R. Dietary sources of lutein and zeaxanthin carotenoids and their role in eye health. Nutrients 2013;5(4): 1169-1185.

40. Davidson KW, Q'Brien ME, Tucker K, Sadowski JA. Dietary intake and plasma concentrations of vitamin K-I S.L. booth. FASEB Journal. 1996;10(3).

41. Gijsbers BLM, Jie KSG, Vermeer C. Effect of food composition on vitamin K absorption in human volunteers. Br J Nutr. 1996;76(2):223-9.

42. Bolton-Smith C, Price RJ, Fenton ST, Harrington DJ, Shearer MJ. Compilation of a provisional UK database for the phylloquinone (vitamin K1) content of foods. Br J Nutr. 2000;83(4):389-99.

43. Hord NG, Tang Y, Bryan NS. Food sources of nitrates and nitrites: the physiologic context for potential health benefits. Am J Clin Nutr. 2009;90(1): $1-10$.

44. Borgi L. Inclusion of phosphorus in the nutrition facts label. Clin J Am Soc Nephrol. 2019;14(1):139-40.

45. Massey LK. Food oxalate: factors affecting measurement, biological variation, and bioavailability. J Am Diet Assoc. 2007;107(7):1191-4 quiz 5-6.

46. Chao PY, Huang MY, Huang WD, Lin KH, Chen SY, Yang CM. Study of chlorophyll-related compounds from dietary spinach in human blood. Notulae Botanicae Horti Agrobotanici Cluj-Napoca. 2018;46(2):309-16.

47. Lynn KS, Cheng ML, Yang HC, Liang YJ, Kang MJ, Chen FL, et al. Vegetable signatures derived from human urinary metabolomic data in controlled feeding studies. Journal of proteome research. 2018.

48. Landis W, Liebman M, Dunn C, Meredith L. Calcium and zinc balances of premenopausal women consuming spinach- compared to cheesecontaining diets. Nutr Res. 1987;7(9):907-14.

49. Passon M, Buhlmeier J, Zimmermann BF, Stratmann A, Latz S, Stehle P, et al. Polyphenol phase-Il metabolites are detectable in human plasma after ingestion of C-13 labeled spinach-a Pilot Intervention Trial in Young Healthy Adults. Molecular Nutrition \& Food Research. 2018:62(10).

50. Serafini M, Bugianesi R, Salucci M, Azzini E, Raguzzini A, Maiani G. Effect of acute ingestion of fresh and stored lettuce (Lactuca sativa) on plasma total antioxidant capacity and antioxidant levels in human subjects. Br J Nutr. 2002:88(6):615-23.

51. DuPont MS, Day AJ, Bennett RN, Mellon FA, Kroon PA. Absorption of kaempferol from endive, a source of kaempferol-3-glucuronide, in humans. Eur J Clin Nutr. 2004;58(6):947-54.

52. Salehi B, Tumer TB, Ozleyen A, Peron G, Dall'Acqua S, Rajkovic J, et al. Plants of the genus Spinacia: from bioactive molecules to food and phytopharmacological applications. Trends Food Sci Technol. 2019;88:26073

53. Roberts $\mathrm{J}$, Moreau R. Functional properties of spinach (Spinacia oleracea L.) phytochemicals and bioactives. Food Function. 2016;7(8):3337-53.

54. Bergquist SÅM, Gertsson UE, Knuthsen P, Olsson ME. Flavonoids in baby spinach (Spinacia oleracea L.): changes during plant growth and storage. J Agricult Food Chem. 2005;53(24):9459-64.

55. Koh E, Charoenprasert S, Mitchell AE. Effect of organic and conventional cropping systems on ascorbic acid, vitamin C, flavonoids, nitrate, and oxalate in 27 varieties of spinach (Spinacia oleracea L.). J Agricult Food Chem. 2012;60(12):3144-50.

56. Singh J, Jayaprakasha GK, Patil BS. Extraction, identification, and potential health benefits of spinach flavonoids: a review. Advances in Plant Phenolics: From Chemistry to Human Health. ACS Symposium Series. 1286: American Chemical Society; 2018. p. 107-36.

57. Ferruzzi MG, Blakeslee J. Digestion, absorption, and cancer preventative activity of dietary chlorophyll derivatives. Nutr Res. 2007;27(1):1-12.

58. Khachik F, Beecher GR, Whittaker NF. Separation, identification, and quantification of the major carotenoid and chlorophyll constituents in extracts of several green vegetables by liquid chromatography. J Agricult Food Chem. 1986;34(4):603-16.

59. Ross AB, Svelander C, Undeland I, Pinto R, Sandberg AS. Herring and beef meals Lead to differences in plasma 2-Aminoadipic acid, beta-alanine, 4Hydroxyproline, cetoleic acid, and docosahexaenoic acid concentrations in overweight men. J Nutr. 2015;145(11):2456-63.

60. Chadwick M, Trewin H, Gawthrop F, Wagstaff C. Sesquiterpenoids lactones: benefits to plants and people. Int J Mol Sci. 2013;14(6):12780-805.

61. Ferioli F, Manco MA, D'Antuono LF. Variation of sesquiterpene lactones and phenolics in chicory and endive germplasm. J Food Compos Anal. 2015;39: $77-86$. 
62. Pei K, Ou J, Huang J, Ou S. P-Coumaric acid and its conjugates: dietary sources, pharmacokinetic properties and biological activities. J Sci Food Agric. 2016;96(9):2952-62.

63. Radtke J, Linseisen J, Wolfram G. Phenolic acid intake of adults in a Bavarian subgroup of the national food consumption survey. Zeitschrift fur Ernahrungswissenschaft. 1998;37(2):190-7.

64. Riaz A, Rasul A, Hussain G, Zahoor MK, Jabeen F, Subhani Z, et al. Astragalin: a bioactive phytochemical with potential therapeutic activities. Adv Pharmacol Sci. 2018;2018:9794625.

65. White $\mathrm{RH}$. Occurrence of S-methyl thioesters in urines of humans after they have eaten asparagus. Science (New York, NY). 1975;189(4205):810-1.

66. Waring RH, Mitchell SC, Fenwick GR. The chemical nature of the urinary odour produced by man after asparagus ingestion. Xenobiotica; the fate of foreign compounds in biological systems. 1987;17(11):1363-71.

67. Azzini E, Bugianesi R, Romano F, Di Venere D, Miccadei S, Durazzo A, et al. Absorption and metabolism of bioactive molecules after oral consumption of cooked edible heads of Cynara scolymus L. (cultivar Violetto di Provenza) in human subjects: a pilot study. Br J Nutr. 2007;97(5):963-9.

68. Rechner AR, Pannala AS, Rice-Evans CA. Caffeic acid derivatives in artichoke extract are metabolised to phenolic acids in vivo. Free Radic Res. 2001;35(2): 195-202.

69. Wittemer SM, Ploch M, Windeck T, Muller SC, Drewelow B, Derendorf H, et al. Bioavailability and pharmacokinetics of caffeoylquinic acids and flavonoids after oral administration of artichoke leaf extracts in humans. Phytomedicine. 2005;12(1-2):28-38.

70. Cao J, Zhang Y, Chen W, Zhao X. The relationship between fasting plasma concentrations of selected flavonoids and their ordinary dietary intake. $\mathrm{Br}$. Nutr. 2010;103(2):249-55.

71. Chrubasik C, Maier T, Dawid C, Torda T, Schieber A, Hofmann T, et al. An observational study and quantification of the actives in a supplement with Sambucus nigra and Asparagus officinalis used for weight reduction. Phytother Res. 2008;22(7):913-8.

72. Dawid C, Hofmann T. Quantitation and bitter taste contribution of saponins in fresh and cooked white asparagus (Asparagus officinalis L.). Food Chem. 2014; 145:427-36

73. Siomos AS. The quality of asparagus as affected by preharvest factors. Scientia horticulturae. 2018;v. 233:pp. 510-9-2018 v.233.

74. Mitchell SC, Waring RH. Asparagusic acid. Phytochemistry. 2014:97:5-10.

75. Pelchat ML, Bykowski C, Duke FF, Reed DR. Excretion and perception of a characteristic odor in urine after asparagus ingestion: a psychophysical and genetic study. Chem Senses. 2011;36(1):9-17.

76. Hostetler GL, Ralston RA, Schwartz SJ. Flavones: food sources, bioavailability, metabolism, and bioactivity. Adv Nutr. 2017;8(3):423-35.

77. Lattanzio V, Kroon PA, Linsalata V, Cardinali A. Globe artichoke: a functional food and source of nutraceutical ingredients. J Funct Foods. 2009;1(2):13144.

78. Rondanelli M, Giacosa A, Opizzi A, Faliva MA, Sala P, Perna S, et al. Beneficial effects of artichoke leaf extract supplementation on increasing $\mathrm{HDL}$-cholesterol in subjects with primary mild hypercholesterolaemia: a double-blind, randomized, placebo-controlled trial. Int J Food Sci Nutr. 2013;64(1):7-15.

79. Santos HO, Bueno AA, Mota JF. The effect of artichoke on lipid profile: a review of possible mechanisms of action. Pharmacol Res. 2018;137:170-8.

80. Scalbert A, Brennan L, Manach C, Andres-Lacueva C, Dragsted LO, Draper J, et al. The food metabolome: a window over dietary exposure. Am J Clin Nutr. 2014;99(6):1286-308.

81. Pujos-Guillot E, Hubert J, Martin JF, Lyan B, Quintana M, Claude S, et al. Mass spectrometry-based metabolomics for the discovery of biomarkers of fruit and vegetable intake: citrus fruit as a case study. J Proteome Res. 2013;12(4): 1645-59.

82. Madrid-Gambin F, Llorach R, Vazquez-Fresno R, Urpi-Sarda M, AlmanzaAguilera E, Garcia-Aloy M, et al. Urinary (1)H nuclear magnetic resonance Metabolomic fingerprinting reveals biomarkers of pulse consumption related to energy-metabolism modulation in a subcohort from the PREDIMED study. J Proteome Res. 2017;16(4):1483-91.

83. Agte V, Jahagirdar M, Chiplonkar S. GLV supplements increased plasma beta-carotene, vitamin C, zinc and hemoglobin in young healthy adults. Eur J Nutr. 2006;45(1):29-36.

84. Andersson $\mathrm{H}$, Gillberg R. Urinary oxalate on a high-oxalate diet as a clinical test of malabsorption. Lancet (London, England). 1977;2(8040):677-9.

85. Asai A, Yonekura L, Nagao A. Low bioavailability of dietary epoxyxanthophylls in humans. Br J Nutr. 2008;100(2):273-7.
86. Brinkley L, McGuire J, Gregory J, Pak CY. Bioavailability of oxalate in foods. Urology. 1981;17(6):534-8.

87. Brogren M, Savage GP. Bioavailability of soluble oxalate from spinach eaten with and without milk products. Asia Pac J Clin Nutr. 2003;12(2):219-24.

88. Bub A, Watzl B, Abrahamse L, Delincee H, Adam S, Wever J, et al. Moderate intervention with carotenoid-rich vegetable products reduces lipid peroxidation in men. J Nutr. 2000;130(9):2200-6.

89. Cardinault N, Tyssandier V, Grolier P, Winklhofer-Roob BM, Ribalta J, Bouteloup-Demange $\mathrm{C}$, et al. Comparison of the postprandial chylomicron carotenoid responses in young and older subjects. Eur J Nutr. 2003;42(6): 315-23.

90. Castenmiller JJ, Lauridsen ST, Dragsted LO, van het Hof KH, Linssen JP, West CE. Beta-carotene does not change markers of enzymatic and nonenzymatic antioxidant activity in human blood. J Nutr. 1999a;129(12): 2162-9.

91. Castenmiller JJ, West CE, Linssen JP, van het Hof KH, Voragen AG. The food matrix of spinach is a limiting factor in determining the bioavailability of beta-carotene and to a lesser extent of lutein in humans. J Nutr. 1999b; 129(2):349-55.

92. Castenmiller JJ, van de Poll CJ, West CE, Brouwer IA, Thomas CM, van Dusseldorp M. Bioavailability of folate from processed spinach in humans. Effect of food matrix and interaction with carotenoids. Ann Nutr Metabol. 2000;44(4):163-9.

93. Cao G, Russell RM, Lischner N, Prior RL. Serum antioxidant capacity is increased by consumption of strawberries, spinach, red wine or vitamin C in elderly women. J Nutr. 1998;128(12):2383-90.

94. Chung HY, Rasmussen HM, Johnson EJ. Lutein bioavailability is higher from lutein-enriched eggs than from supplements and spinach in men. J Nutr. 2004;134(8):1887-93.

95. Corte-Real J, Guignard C, Gantenbein M, Weber B, Burgard K, Hoffmann L, et al. No influence of supplemental dietary calcium intake on the bioavailability of spinach carotenoids in humans. Br J Nutr. 2017;117(11): 1560-9.

96. Clark NA, Teschke K, Rideout K, Copes R. Trace element levels in adults from the west coast of Canada and associations with age, gender, diet, activities, and levels of other trace elements. Chemosphere. 2007;70(1):155-64.

97. Dainty JR, Bullock NR, Hart DJ, Hewson AT, Turner R, Finglas PM, et al. Quantification of the bioavailability of riboflavin from foods by use of stableisotope labels and kinetic modeling. Am J Clin Nutr. 2007;85(6):1557-64.

98. Doane LT, Liebman M, Caldwell DR. Microbial oxalate degradation: effects on oxalate and calcium balance in humans. Nutr Res. 1989;9(9):957-64.

99. Edwards AJ, You CS, Swanson JE, Parker RS. A novel extrinsic reference method for assessing the vitamin a value of plant foods. Am J Clin Nutr. 2001;74(3):348-55.

100. Faulks RM, Hart DJ, Brett GM, Dainty JR, Southon S. Kinetics of gastrointestinal transit and carotenoid absorption and disposal in ileostomy volunteers fed spinach meals. Eur J Nutr. 2004:43(1):15-22.

101. Froeder L, Arasaki CH, Malheiros CA, Baxmann AC, Heilberg IP. Response to dietary oxalate after bariatric surgery. Clin J Am Soc Nephrol. 2012;7(12): 2033-40.

102. Garber AK, Binkley NC, Krueger DC, Suttie JW. Comparison of phylloquinone bioavailability from food sources or a supplement in human subjects. J Nutr. 1999:129(6):1201-3.

103. Gough TA, Webb KS, Swann PF. An examination of human blood for the presence of volatile nitrosamines. Food Chem Toxicol. 1983;21(2):151-6.

104. Graydon R, Hogg RE, Chakravarthy U, Young IS, Woodside JV. The effect of lutein- and zeaxanthin-rich foods $v$. supplements on macular pigment level and serological markers of endothelial activation, inflammation and oxidation: pilot studies in healthy volunteers. Br J Nutr. 2012;108(2):334-42.

105. Hammond BR Jr, Johnson EJ, Russell RM, Krinsky NI, Yeum KJ, Edwards RB, et al. Dietary modification of human macular pigment density. Invest Ophthalmol Vis Sci. 1997:38(9):1795-801.

106. Hanson CF, Frankos VH, Thompson WO. Bioavailability of oxalic acid from spinach, sugar beet fibre and a solution of sodium oxalate consumed by female volunteers. Food Chem Toxicol. 1989;27(3):181-4.

107. Haskell MJ, Jamil KM, Hassan F, Peerson JM, Hossain MI, Fuchs GJ, et al. Daily consumption of Indian spinach (Basella alba) or sweet potatoes has a positive effect on total-body vitamin a stores in Bangladeshi men. Am J Clin Nutr. 2004;80(3):705-14.

108. Hussein L. El-Tohamy M. vitamin a potency of carrot and spinach carotenes in human metabolic studies. International journal for vitamin and nutrition 
research Internationale Zeitschrift fur Vitamin- und Ernahrungsforschung Journal international de vitaminologie et de nutrition. 1990;60(3):229-35.

109. Johnson EJ, Hammond BR, Yeum KJ, Qin J, Wang XD, Castaneda C, et al. Relation among serum and tissue concentrations of lutein and zeaxanthin and macular pigment density. Am J Clin Nutr. 2000;71(6):1555-62.

110. Jonvik KL, Nyakayiru J, Pinckaers PJ, Senden JM, van Loon LJ, Verdijk LB. Nitrate-rich vegetables increase plasma nitrate and nitrite concentrations and lower blood pressure in healthy adults. J Nutr. 2016;146(5):986-93.

111. Karkkainen MU, Wiersma JW, Lamberg-Allardt CJ. Postprandial parathyroid hormone response to four calcium-rich foodstuffs. Am J Clin Nutr. 1997; 65(6):1726-30

112. Konings EJ, Troost FJ, Castenmiller JJ, Roomans HH, Van Den Brandt PA, Saris WH. Intestinal absorption of different types of folate in healthy subjects with an ileostomy. Br J Nutr. 2002;88(3):235-42.

113. Kopsell DA, Lefsrud MG. Spinach cultigen variation for tissue carotenoid concentrations influences human serum carotenoid levels and macular pigment optical density following a 12-week dietary intervention. J Agric Food Chem. 2006:54(21):7998-8005.

114. Lakritz L, Gates RA, Gugger AM, Wasserman AE. Nitrosamine levels in human blood, urine and gastric aspirate following ingestion of foods containing potential nitrosamine precursors or preformed nitrosamines. Food Chem Toxicol. 1982;20(4):455-9.

115. Lienau A, Glaser T, Tang G, Dolnikowski GG, Grusak MA, Albert K. Bioavailability of lutein in humans from intrinsically labeled vegetables determined by LC-APCI-MS. J Nutr Biochem. 2003;14(11):663-70.

116. Lovalvo JL, Rock CL, Ruffin MT, Emenhiser C, Disario W, Schwartz SJ. $\beta$ carotene uptake from processed versus raw vegetables in women. FASEB Journal. 1996;10(3)

117. Martini MC, Campbell DR, Gross MD, Grandits GA, Potter JD, Slavin JL. Plasma carotenoids as biomarkers of vegetable intake: the University of Minnesota Cancer Prevention Research Unit Feeding studies. Cancer Epidemiol Biomark Prev. 1995:4(5):491-6.

118. Maruyama C, Kikuchi N, Masuya Y, Hirota S, Araki R, Maruyama T. Effects of green-leafy vegetable intake on postprandial glycemic and lipidemic responses and alpha-tocopherol concentration in normal weight and obese men. J Nutr Sci Vitaminol. 2013;59(4):264-71

119. McKillop DJ, McNulty H, Scott JM, McPartlin JM, Strain JJ, Bradbury l, et al. The rate of intestinal absorption of natural food folates is not related to the extent of folate conjugation. Am J Clin Nutr. 2006;84(1):167-73.

120. Mito N, Takimoto $H$, Umegaki K, Ishiwaki A, Kusama K, Fukuoka H, et al. Folate intakes and folate biomarker profiles of pregnant Japanese women in the first trimester. Eur J Clin Nutr. 2007;61(1):83-90.

121. Monch S, Netzel M, Netzel G, Ott U, Frank T, Rychlik M. Folate bioavailability from foods rich in folates assessed in a short term human study using stable isotope dilution assays. Food Funct. 2015:6(1):242-8.

122. Moser B, Szekeres T, Bieglmayer C, Wagner KH, Misik M, Kundi M, et al. Impact of spinach consumption on DNA stability in peripheral lymphocytes and on biochemical blood parameters: results of a human intervention trial. Eur J Nutr. 2011;50(7):587-94.

123. Muller H, Bub A, Watzl B, Rechkemmer G. Plasma concentrations of carotenoids in healthy volunteers after intervention with carotenoid-rich foods. Eur J Nutr. 1999;38(1):35-44.

124. Paiva SA, Yeum KJ, Cao G, Prior RL, Russell RM. Postprandial plasma carotenoid responses following consumption of strawberries, red wine, vitamin C or spinach by elderly women. J Nutr. 1998;128(12):2391-4.

125. Prinz-Langenohl R, Bronstrup A, Thorand B, Hages M, Pietrzik K. Availability of food folate in humans. J Nutr. 1999;129(4):913-6.

126. Riso P, Brusamolino A, Ciappellano S, Porrini M. Comparison of lutein bioavailability from vegetables and supplement. International journal for vitamin and nutrition research Internationale Zeitschrift fur Vitamin- und Ernahrungsforschung Journal international de vitaminologie et de nutrition. 2003;73(3):201-5

127. Riso P, Brusamolino A, Scalfi L, Porrini M. Bioavailability of carotenoids from spinach and tomatoes. Nutr Metabol cardiovasc Diseas. 2004;14(3):150-6.

128. Rock CL, Lovalvo JL, Emenhiser C, Ruffin MT, Flatt SW, Schwartz SJ. Bioavailability of beta-carotene is lower in raw than in processed carrots and spinach in women. J Nutr. 1998;128(5):913-6.

129. Ruhl R, Bub A, Watzl B. Modulation of plasma all-trans retinoic acid concentrations by the consumption of carotenoid-rich vegetables. Nutrition (Burbank, Los Angeles County, Calif). 2008;24(11-12):1224-6.
130. Rychlik M, Netzel M, Pfannebecker I, Frank T, Bitsch I. Application of stable isotope dilution assays based on liquid chromatography-tandem mass spectrometry for the assessment of folate bioavailability. J Chromatogr B Anal Technol Biomed Life Sci. 2003:792(2):167-76.

131. Schirrmacher G, Skurk T, Hauner H, Graßmann J. Effect of Spinacia oleraceae $L$. and perilla frutescens $L$. on antioxidants and lipid peroxidation in an intervention study in healthy individuals. Plant Foods Hum Nutr. 2010;65(1): 71-6.

132. Scholfield DJ, Behall KM, Kelsay JL, Prather ES, Clark WM, Reiser S, et al. The effects of natural dietary fiber from fruit and vegetables with oxalate from spinach on plasma minerals, lipids and other metabolites in men. Nutr Res. 1990;10(4):367-78.

133. Schurgers $L$, Vermeer $C$. Determination of phylloquinone and menaquinones in food. Effect of food matrix on circulating vitamin $\mathrm{K}$ concentrations. Haemostasis. 2000:30(6):298-307.

134. Tang G, Qin J, Dolnikowski GG, Russell RM, Grusak MA. Spinach or carrots can supply significant amounts of vitamin a as assessed by feeding with intrinsically deuterated vegetables. Am J Clin Nutr. 2005;82(4):821-8.

135. Tyssandier V, Cardinault N, Caris-Veyrat C, Amiot MJ, Grolier P, Bouteloup C, et al. Vegetable-borne lutein, lycopene, and beta-carotene compete for incorporation into chylomicrons, with no adverse effect on the mediumterm (3-wk) plasma status of carotenoids in humans. Am J Clin Nutr. 2002 75(3):526-34.

136. Tyssandier V, Reboul E, Dumas JF, Bougteloup-Demange C, Armand M, Marcand J, et al. Processing of vegetable-borne carotenoids in the human stomach and duodenum. Am JPhysiol Gastrointest Liver Physiol. 2003; 284(6):G913-G23.

137. van den Berg $H$, van Vliet $T$. Effect of simultaneous, single oral doses of beta-carotene with lutein or lycopene on the beta-carotene and retinyl ester responses in the triacylglycerol-rich lipoprotein fraction of men. Am J Clin Nutr. 1998;68(1):82-9.

138. van het Hof KH, Tijburg LB, Pietrzik K, Weststrate JA. Influence of feeding different vegetables on plasma levels of carotenoids, folate and vitamin C. effect of disruption of the vegetable matrix. Br J Nutr. 1999;82(3):203-12.

139. van Velzen AG, Sips A, Schothorst RC, Lambers AC, Meulenbelt J. The oral bioavailability of nitrate from nitrate-rich vegetables in humans. Toxicol Lett. 2008;181(3):177-81.

140. Van Lieshout M, West CE, Van De Bovenkamp P, Wang Y, Sun Y, Van Breemen RB, et al. Extraction of carotenoids from feces, enabling the bioavailability of beta-carotene to be studied in Indonesian children. J Agric Food Chem. 2003;51(17):5123-30

141. van Maanen JM, Pachen DM, Dallinga JW, Kleinjans JC. Formation of nitrosamines during consumption of nitrate- and amine-rich foods, and the influence of the use of mouthwashes. Cancer Detect Prev. 1998:22(3):20412

142. Gomez-Aracena J, Bogers R, Van't Veer P, Gomez-Gracia E, Garcia-Rodriguez A, Wedel $\mathrm{H}$, et al. Vegetable consumption and carotenoids in plasma and adipose tissue in Malaga, Spain. International journal for vitamin and nutrition research Internationale Zeitschrift fur Vitamin- und Ernahrungsforschung Journal international de vitaminologie et de nutrition. 2003;73(1):24-31.

143. Yang Z, Zhang Z, Penniston KL, Binkley N, Tanumihardjo SA. Serum carotenoid concentrations in postmenopausal women from the United States with and without osteoporosis. International journal for vitamin and nutrition research Internationale Zeitschrift fur Vitamin- und Ernahrungsforschung Journal international de vitaminologie et de nutrition. 2008;78(3):105-11.

144. Al-Attabi Z, D'Arcy BR, Deeth HC. Volatile Sulphur compounds in UHT milk. Crit Rev Food Sci Nutr. 2009;49(1):28-47.

\section{Publisher's Note}

Springer Nature remains neutral with regard to jurisdictional claims in published maps and institutional affiliations. 